\title{
Factors Determining The Quality Of Research Processes In Management Sciences
}

\author{
Henryk DŹWIGOt \\ Silesian University of Technology, Faculty of Organization and Management, Poland \\ henryk.dzwigol@polsl.pl
}

\begin{abstract}
The aim of the article was to determine factors that would influence the quality of a research process, as an element that supplements currently used methodology-related approaches. As a result of empirical studies, the main aim hereof and detailed aims were achieved. The article presented the research methodology in the management sciences. Research findings were discussed, i.e. factors that determine the quality of the process and research methods. The author analysed how the practical approach influenced the quality of research process. The necessity of employing diverse research methods in research processes was highlighted.
\end{abstract}

Keywords: methodology, research process, research methods.

\section{Introduction}

In the today's science and economy ( $21^{\text {st }}$ century) we have been witnessing development of management sciences, aiming at making use of non-complicated and complete methods in order to ponder on each aspect of the same problem (Coghlan, Shani, 2016; Collins, 2010; Harrington, 2016). Managing of a today's company necessitates not only to enhance its effectiveness, but also improve the company's value (Gerring, 2017; Mooi, Sarstedt, Mooi-Reci, 2018). Due to changes occurring in the environment of the company, it has been necessary to elaborate new rules, principles and ways for the company operation, as well as new management systems (O’Leary, Hunt, 2016; Petrova, 2018). With reference to that, the $21^{\text {st }}$ century management sciences had to adopt a new paradigm; it was based on the ability to cope with continuous changes. It is said that a change is the only permanent phenomenon in the modern economic world (Sloan, 2017; Singleton, 2017).

Empirical research methods are proper methods for management sciences. Within their scope one should employ adequate methods allowing to verify research hypotheses and answer research questions. Deductive methods, analogical reasoning, complemented with intuition should be a source of research hypotheses or a basis for formulating research questions. Carrying out research as to management sciences requires more research discipline than the above-mentioned intuition (Niemczyk, 2017, pp. 19-20). The determined management-related principles are, more often than not, of 'soft' character; they are understood in various ways. In management sciences it is very easy to create 'new theories' that are not finally verified (Thomas, 2017; Robbins, 2009; Quinton, Reynolds, 2018; O'Leary, 2017; Labarca, 2017). A rapid introduction of new, recommended managementrelated concepts and methods, as well as their fast rejection resulted in negative organisational changes. It would be difficult to identify the reasons why the applied methods are ineffective. Was the failure triggered by an inadequate method used for a management process or by its unskilful implementation (Sudol, 2012, pp. 21-24). The problem lies in the overproduction of

The current issue and full text archive of this journal is available a www.jraspublications.org/index.php/JRAS/issue/archive Journal of Research in Administrative Sciences (JRAS)

VII(II), 25-31, ISSN: 2664-2433 research findings and publications, being useless or not fully valuable (Sułkowski, 2010, p. 321). Management sciences are deprived of an explicit false-truth criterion (Koźmiński, 2011, p. 125). Management sciences lack one, commonly accepted paradigm, understood as a set of basic cognitive assumptions. If that was the case, the said assumptions would provide for a predominant approach in the discipline, blending all approaches, trends and schools (Sudoł, 2007, p. 19). Therefore, should one look for such a paradigm in management sciences? (Jokiel, 2006, pp. 57-63). It needs to be stated that, in spite of critical views, both management sciences and their methods and methodology result in the improved effectiveness and competitiveness of companies. However, it needs to be mentioned that management methods are not and cannot be of universal character. The methods must be changed as the times goes by, as the company changes over the years (Punch, 2016; Quian, 2018).

In modern management science, research and analyses focus mainly on the quality of the research process. The latter influences the accuracy and quality of decisions taken. The difference between the modern and traditional approach is significant. In the traditional approach to the management (in particular with reference to research processes) the main stress is put on finding answers to the following questions:

- Which elements - of an organisation, process, etc. are not working properly?

- Which elements should be regarded as inappropriate?

What are the reasons of that?

The traditional approach does not always allow to achieve satisfactory results; what is more, it does not always result in improving the existing situation. Within the scope of the contemporary approach, various types of principles, procedures or tools are elaborated. They allow, contrary to the traditional approach, to enhance the knowledge of the existing problem situation (Ares, Varela, 2018). To this end, one may adopt the following perspective - the Positive Organizational Scholarship (SOP). Upon its implementation, one needs to pose a basic 
question, i.e.: Why are some employees so ineffective? Then, the following questions are asked:

- Why is it so?

- What are the reasons for such a phenomenon?

As a result of the applied SOP perspective, one will find an answer to the following question - what needs to be done to achieve the desired state, i.e. what needs to be done to be good at something and how to achieve perfection.

In modern management science, the methodological fundamentalism was rejected, which stringently defined the scientific character of a method, evoking neo-positivist models in natural sciences. (Hempoliński, 1992). In the literature on management sciences, the necessity to apply numerous selfverifying and self-correcting methods has been highlighted many a time (Denzin, 1970; Collins, 2010; Coghlan, Shani, 2016; Harrington, 2016). Furthermore, there occurred a phenomenon of methodological pluralism. It has advocated that in order to solve a research problem, one should be ready to apply research methods derived from various disciplines and theoretical approaches. It means that 'the multitude of ways in which the world is perceived shall be combined with multitude and diversity of ways, methods, evaluation techniques, and attempts to transform the world' (Krzyżanowski, 1999). However, it very often causes anarchism and methodological eclecticism. With reference to the foregoing, in order to achieve reliable research results, it is necessary to analyse in details a research problem, and consequently select such research methods that would facilitate the avoidance of the abovementioned phenomena.

Conclusions derived from an ongoing analysis of national and foreign literature dealing with methodology of conducting a research process (Sułkowski, 2010; Sudoł, 2012; Boland, Cherry, Dickson, 2017) showed a deficit in empiric approaches to the quality of research processes, where, as a result of transformations over several years in management methods, it is difficult, as early as at the stage of defining a research problem, to select just one method that would allow to diagnose a problem fully and comprehensively. It is thus necessary to employ various research methods that would give a complex answer to the posed problem. That is why the research, as determined in the article, is aimed at selecting factors that would influence the quality of the research process, as an element supporting the ongoing methodologyrelated approaches.

\section{Research Methodology}

Conclusions derived from an ongoing analysis of national and foreign literature dealing with methodology of conducting a research process showed a deficit in empiric approaches to the quality of research processes. Thus, a research problem was defined as follows: What factors determine the quality of research processes in the management sciences?

With reference to the foregoing, the following research questions were posed:

PB 1. What factors may shape the quality of a research process?

PB 2. How can the practical approach (universalism and purposefulness) influence the quality of a research process?

PB 3. Is it necessary to differentiate research methods in research processes?

Giving answers to such a research question will allow to verify the following hypothesis: 'Identifying factors that would determine the quality of a research process is of critical importance to complement ongoing methodology-related approaches in the management sciences.'

In the present work the following main aim was adopted - to identify factors that would influence the quality of a research process, regarded as an element completing the current methodology-related approaches.

Apart from the above-mentioned main aim, some detailed research aims were identified:

E 1 . To statistically identify factors that shape the quality of a research process.

E 2. To determine the influence of the practical approach on the quality of a research process.

E 3. To verify the necessity to differentiate research methods in research processes.
Volume VII, Issue II, 2018, 25-31

In order to receive answers to research questions and execute the determined aims, one elaborated a research model, based on a generally accepted course of action (Weber, 2011), as presented in the Figure 1.

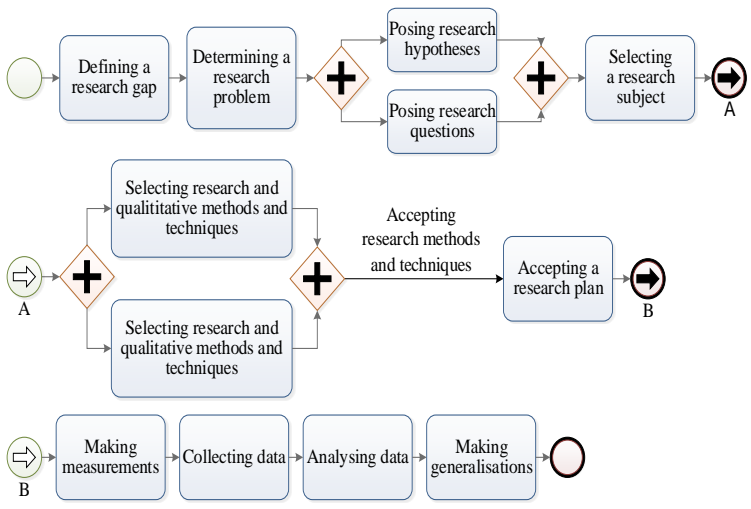

Figure 1. Research model. Source: The author's own work.

\section{Research Subject}

Quantitative research covered theoreticians of management sciences, being a target group. The group consisted of:

- 272 foreign universities having faculties and/or units dealing with management sciences,

- 21,024 foreign academic staff connected to the management sciences,

- 93 national universities having faculties and/or units dealing with management sciences,

- $\quad 2,307$ national academic staff connected to the management sciences,

- 52 foreign companies,

- 183 national companies.

The size of a research sample, necessary to determine a representative character of the research, was determined on the basis of the following assumptions:

- the $p$ fraction ratio was set to $50 \%{ }^{1}$,

- the amount of an error related to the fraction ratio was set to $5 \%$,

statistical significance $\alpha=0.05$.

On the basis of the above-mentioned assumptions, the requested sample size formula will be simplified, and look as follows (Kukuła, 2007):

$$
n_{p}=\frac{u_{\alpha}^{2} * p(1-p)}{b_{p}^{2}}=\frac{u_{\alpha}^{2}}{4 b_{p}^{2}}=\frac{1,96^{2}}{4 * 0,05^{2}}=384,16
$$

where

- $\quad n_{p}$ - requested sample size

- $\quad \mathrm{u}_{\alpha}$ - amount of cumulative normal distribution derived from statistical tables,

- $\quad \mathrm{p}$ - fraction ratio

- $\quad b-$ the size of the fraction ratio error.

As a result of the research effort, 401 representatives of management science theorists were surveyed, thus the condition determining the representative character of the research sample was met.

In the surveyed group of scientists, Polish universities amounted to $32 \%$, whereas foreign universities accounted for $33 \%$. As to the remaining part of the research group (35\%), no academic unit was indicated. The most common areas of sciences in which the researchers were involved where, among others: strategic management, company management, knowledge and innovation management, as well as methodics of the research on organisations.

\footnotetext{
${ }^{1}$ Should the size of population be unknown, the said approach shall be acceptable.
} 


\section{Research Methods}

In order to find answers to the posed research questions, the research study involved an anonymous survey questionnaire (destined for academic staff conducting research studies within the field of management sciences) distributed in a paper form at conferences from the area of management sciences, and electronically, on the basis of an e-mail database, elaborated earlier. The research study was carried out from October 2016 to April 2018. The questionnaire consisted of three parts. The first part contained questions about the importance of approaches, processes, methods and techniques in a research process within the scope of management sciences (5 questions). The second part consisted of questions related to the problem of the improvement of a research process (33 questions). The third part contained demographics ( 3 questions). The structure of the questionnaire in the research part involved both open, rank questions, and questions based on the 5-point Likert scale. Within the scope of the latter, the respondents were obliged to classify a particular answer as: strongly agree (5), agree (4), neither agree nor disagree (3), disagree (2), strongly disagree (1), with reference to each of proposed assumptions.

In order to assess factors that determine the quality of research processes in management sciences, one applied a commonly used method of principal component analysis (PCA), also known as a factor analysis (Trajer, Paszek, Iwan, 2012). The main aim of conducting the factor analysis was to identify all factors being directly correlated to a given set of variables, while maintaining, at the same time, the greatest amount of information contained in initial variables, which was then followed by their reduction (Czopek, 2013)

A statistical analysis of results was conducted by means of a statistical programme named Statistica 13 (https://www.statsoft.pl). The software in question is in a widespread use for the analysis of statistical data (Malska, 2017; Fojud, et al., 2017).

\section{Research Findings}

The analysis of research findings involved their preparation, by means of descriptive statistics tools. At the same time, it needs to be emphasised that the said findings are of preliminary character. They form a basis for further extensive research studies, the latter being subject of various papers.

\subsection{Factors determining the quality of research processes - factor analysis}

In compliance with method-related assumptions, referring to the fulfilment of basic requirements for carrying out the factor analysis, one should take the following steps, destined to prove that the method in question was correctly selected:

- Verification of a number of variables against a number of respondents taking part in the study ${ }^{2}$.

- $\quad$ The Bartlett test (of sphericity).

- The KMO and MSA measures.

In the beginning, the condition referring to the number of observations and variables was studied. In the case in question, 33 variables and 401 surveyed respondents were analysed, which means that the condition was met.

In the Bartlett test, it is possible to find out whether the matrix of the Pearson correlation coefficient is not a unit matrix. The test is performed with the use of test statistics dependent on a number of variables, correlation coefficient and number of variable observations. The test statistics has a chi-square layout. For the purpose of performing the test, the following zero hypothesis $\left(\mathrm{H}_{0}\right)$ and alternative hypothesis $\left(\mathrm{H}_{1}\right)$ were applied:

$\mathrm{H}_{0}$ - the matrix containing variable correlations is a unit matrix.

$\mathrm{H}_{1}-$ the matrix containing variable correlations is not a unit matrix.

${ }^{2}$ The source literature indicates that the number of respondents should be at least two times bigger than the number of variables subject to analyses.
Table 1.

The Bartlett test (of sphericity) (results are relevant when $p<$ $0.05)$

\begin{tabular}{|c|c|c|c|}
\hline Empirical Chi & Levels of freedom & p-value & $\begin{array}{c}\text { Theoretical } \\
\text { Chi }^{2}\end{array}$ \\
\hline 4830.79 & 528 & $<0.001$ & 582.56 \\
\hline
\end{tabular}

Source: the author's own work.

Since the empirical $\mathrm{chi}^{2}$ exceeds the theoretical $\mathrm{chi}^{2}$, the zero hypothesis is rejected in favour of the alternative hypothesis. It therefore transpires that variables can be subject to the factor analysis.

The KMO Measure (Kaiser-Meyer-Olkin Measure of Sampling Adequacy) is a ratio of correlation of variables against a partial correlation of variables. In the covered study, the ratio amounts to 0.835 . It falls within the scale from 0 to 1 , and the greater it is, the more justified the factor analysis is ${ }^{3}$. The more accurate test is the MSA Measure (Measure of Sampling Adequacy) since it is defined for each question (variable). If the MSA coefficient for a given question is lower than 0.5 , then one should consider removing the said variable from the analysis. On the basis of the Table no. 2 it might be found out that each question met the MSA threshold. Thus, a conclusion may be drawn that all requirements in the analysis were met.

Table 2.

Results of the MSA analysis

\begin{tabular}{|l|l|l|}
\hline \multicolumn{1}{|c|}{ Question } & $\begin{array}{c}\text { Variable } \\
\text { number }\end{array}$ & $\begin{array}{c}\text { MSA } \\
\text { reference }\end{array}$ \\
\hline $\begin{array}{l}\text { Is the Management science discipline } \\
\text { destined to support practical aspects of } \\
\text { the economic life? }\end{array}$ & $\mathrm{P} 1$ & 0.850 \\
\hline $\begin{array}{l}\text { Should a researcher provide models of } \\
\text { effective organisation- and } \\
\text { management-related solutions? }\end{array}$ & $\mathrm{P} 2$ & 0.805 \\
\hline $\begin{array}{l}\text { Should a researcher provide methods to } \\
\text { implement models of effective } \\
\text { solutions? }\end{array}$ & $\mathrm{P} 3$ & 0.818 \\
\hline $\begin{array}{l}\text { Is it necessary that the research studies, } \\
\text { carried out within the scope of the } \\
\text { Management science discipline, be } \\
\text { practically and theoretically set? }\end{array}$ & $\mathrm{P} 4$ & 0.869 \\
\hline $\begin{array}{l}\text { Is the instability of statements the main } \\
\text { drawback connected to the Management } \\
\text { science? }\end{array}$ & $\mathrm{P} 5$ & 0.873 \\
\hline $\begin{array}{l}\text { Does the research cover, in most cases, } \\
\text { those variables which depend on } \\
\text { various conditions: operating } \\
\text { conditions, weather and environmental } \\
\text { conditions, legal or social conditions, } \\
\text { etc? }\end{array}$ & $\mathrm{P} 6$ & 0.856 \\
\hline $\begin{array}{l}\text { Does the complexity of research objects } \\
\text { (e.g. companies) have a negative impact } \\
\text { on the credibility of research findings? }\end{array}$ & $\mathrm{P} 7$ & 0.883 \\
\hline $\begin{array}{l}\text { Does the application of qualitative } \\
\text { factors, difficult to measure, affect the } \\
\text { quality of a research process? }\end{array}$ & $\mathrm{P} 8$ & \\
\hline $\begin{array}{l}\text { Are the advocated and applied methods } \\
\text { assessed differently by management } \\
\text { theorists and practitioners? }\end{array}$ & $\mathrm{P} 9$ \\
\hline $\begin{array}{l}\text { Are there any problems in terms of } \\
\text { verifiability of findings of research } \\
\text { studies, carried out in the Management } \\
\text { science discipline? }\end{array}$ & $\mathrm{P} 10$ & 0.790 \\
\hline $\begin{array}{l}\text { Should the co-operation between } \\
\text { science and business practice be of } \\
\text { strategic character in the process of } \\
\text { managing a modern company? }\end{array}$ & $\mathrm{P} 11$ & \\
\hline In the management sciences, does the & \\
\hline
\end{tabular}

${ }^{3}$ Practically, the threshold of 0.5 or over is adopted. Exceeding of the threshold makes that an analysis of a set of variables is regarded as justifiable. 


\begin{tabular}{|c|c|c|}
\hline $\begin{array}{l}\text { time between posing a problem, } \\
\text { analysing and finding a solution to the } \\
\text { problem, and implementing the said } \\
\text { solution have a negative impact on the } \\
\text { effectiveness of the solution? }\end{array}$ & & \\
\hline $\begin{array}{l}\text { Is there universalism of elaborated } \\
\text { concepts, solutions to problems in the } \\
\text { management sciences? }\end{array}$ & P13 & 0.794 \\
\hline $\begin{array}{l}\text { Is the methodological triangulation a } \\
\text { prerequisite in research processes? }\end{array}$ & P14 & 0.802 \\
\hline $\begin{array}{l}\text { Should qualitative methods in research } \\
\text { processes be completed with case } \\
\text { studies? }\end{array}$ & P15 & 0.865 \\
\hline $\begin{array}{l}\text { Is it necessary, in order to make the } \\
\text { research reliable, to verify the } \\
\text { elaborated methods, procedures and } \\
\text { models in practice? }\end{array}$ & P16 & 0.860 \\
\hline $\begin{array}{l}\text { Can pilot studies affect the direction of } \\
\text { a research process? }\end{array}$ & P17 & 0.875 \\
\hline $\begin{array}{l}\text { Is it necessary to create a model, } \\
\text { procedure, tool or approach for the sake } \\
\text { of a research process? }\end{array}$ & P18 & 0.885 \\
\hline $\begin{array}{l}\text { Is it possible for a researcher to match } \\
\text { chosen methods to the character of the } \\
\text { research study in question? }\end{array}$ & P19 & 0.701 \\
\hline $\begin{array}{l}\text { Does a researcher have an impact on } \\
\text { combining qualitative and quantitative } \\
\text { methods in a research process? }\end{array}$ & $\mathrm{P} 20$ & 0.720 \\
\hline $\begin{array}{l}\text { Do pilot studies affect the course of a } \\
\text { research process? }\end{array}$ & $\mathrm{P} 21$ & 0.862 \\
\hline $\begin{array}{l}\text { Does the elaboration of models, } \\
\text { procedures, tools or approaches in the } \\
\text { research process guarantee the } \\
\text { credibility of results? }\end{array}$ & $\mathrm{P} 22$ & 0.884 \\
\hline $\begin{array}{l}\text { Is it necessary to elaborate assumptions } \\
\text { in order to create research methodics? }\end{array}$ & $\mathrm{P} 23$ & 0.884 \\
\hline $\begin{array}{l}\text { Do the recommendation for } \\
\text { management science and practice, } \\
\text { elaborated on the basis of research } \\
\text { results, improve the quality of science } \\
\text { and practice? }\end{array}$ & P24 & 0.845 \\
\hline $\begin{array}{l}\text { Does the elaborated model, procedure, } \\
\text { tool or approach to the methods selected } \\
\text { for a research process considerably } \\
\text { affect the quality and application of } \\
\text { research results? }\end{array}$ & $\mathrm{P} 25$ & 0,823 \\
\hline $\begin{array}{l}\text { Is it necessary, upon determining the } \\
\text { research problem, to analyse selected } \\
\text { qualitative and quantitative methods, in } \\
\text { order to make a preliminary selection? }\end{array}$ & P26 & 0.840 \\
\hline $\begin{array}{l}\text { Are pilot studies an integral component } \\
\text { of each research process? }\end{array}$ & P27 & 0.801 \\
\hline $\begin{array}{l}\text { Is the verification of elaborated } \\
\text { methods, models or procedures a } \\
\text { prerequisite to combine management } \\
\text { science and practice? }\end{array}$ & $\mathrm{P} 28$ & 0.856 \\
\hline $\begin{array}{l}\text { Does the methodological triangulation } \\
\text { support research processes? }\end{array}$ & P29 & 0.843 \\
\hline $\begin{array}{l}\text { Does a case study allow to perform an } \\
\text { in-depth analysis of a research process? }\end{array}$ & P30 & 0.813 \\
\hline $\begin{array}{l}\text { Should the expert group assessment be } \\
\text { regarded as a basic method of } \\
\text { evaluating trends of the carried-out } \\
\text { research? }\end{array}$ & P31 & 0.849 \\
\hline $\begin{array}{l}\text { Is it important to carry out observations } \\
\text { of research studies in natural conditions, } \\
\text { in which a researcher co-operates with } \\
\text { researched subjects? }\end{array}$ & P32 & 0.794 \\
\hline $\begin{array}{l}\text { What is the importance of observation- } \\
\text { interventions conducted with the scope } \\
\text { of managerial activity in the researched } \\
\text { subjects, whereas a researcher can } \\
\text { directly influence the decisions taken? }\end{array}$ & P33 & 0.766 \\
\hline
\end{tabular}

Source: the author's own work.
The factor analysis involves selecting of the so-called factors. The said factors, in principle, are to describe determinants that are common for a central determinant. In the case in question, the research process is regarded as the central determinant. A consequence of selecting the said analysis is the transformation of observations, where each factor to be selected needs to meet the Keiser criterion. While adopting the approach, one needs to remember that the extent to which a given phenomenon was explained by a given factor is shown by a ratio between its eigenvalue and its number of variables ${ }^{4}$.

The scree plot is a graphical representation of factors that meet the Keiser criterion.

On the basis of results presented in the Figure 2, 8 factors were identified. The said factors met the above-mentioned Keiser criterion. Thus, it was decided that the number would be sufficient to illustrate the problem.

Another step involves selecting a type of factor rotation. Basic types of orthogonal rotations cover:

- VARIMAX - it is a standard rotation in numerous statistical tools; it facilitates the interpretation of a factor through reducing a number of variables with high loads on each factor.

- QUARTIMAX - it facilitates the interpretation of variables in terms of factors, through reducing a number of factors necessary to explain a given variable.

- EQUAMAX - it facilitates the interpretation of both variables and factors. It is a combination of VARIMAX and QUARTIMAX methods.

Figure 2. Scree plot for researched variables. Source: the author's own work.

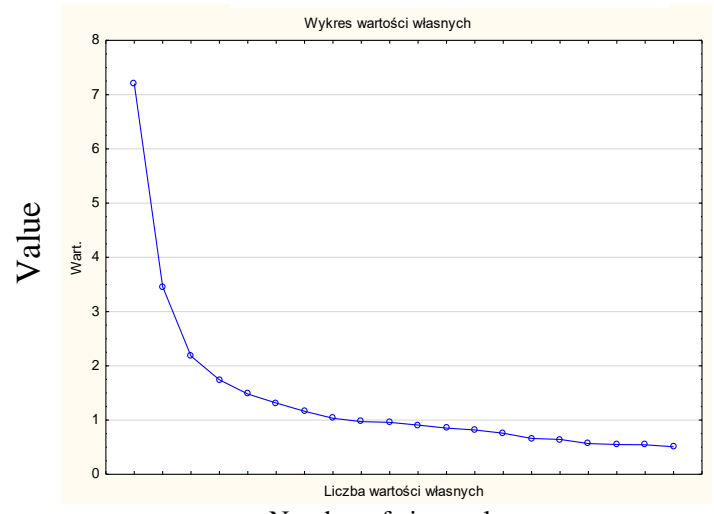

Number of eigenvalues

In the analysed case, un saum surauvi was pusunucd with the use of the EQUAMAX method which allows to distribute, in an uniform way, a variance between factors. The method also reduce the number of factors required for the sake of explaining variances. The threshold loading was set to 0.5 . In the case in question, by means of 8 defined factors, one is able to explain $59.32 \%$ of the research process.

The Figure 3 shows determinants of a research process, as defined by means of the EQUAMAX rotation.

\footnotetext{
${ }^{4}$ Factors may, but do not have to correspond to factors stated in the literature, as the continuous development of management science is a natural and needed occurrence. Following the factors contained in the literature in a rigid way results, more often than not, in making a research problem (as described with the use of the factors) shallow.
} 
Henryk DŹWIGOt

\begin{tabular}{|c|c|}
\hline $\begin{array}{l}\text { Questions } \\
\text { P1 - P4 }\end{array}$ & Practical application and purposefulness \\
\hline $\begin{array}{c}\text { Questions } \\
\text { P5 - P8, P11, P }\end{array}$ & $\begin{array}{l}\text { Influence of diverse research problems on the } \\
\text { research process }\end{array}$ \\
\hline $\begin{array}{l}\text { Questions } \\
\text { P19-P21 }\end{array}$ & Influence of a researcher on the research process \\
\hline $\begin{array}{l}\text { Questions } \\
\text { P9 - P10 }\end{array}$ & Unique character of a scientific discipline \\
\hline $\begin{array}{l}\text { Questions } \\
\text { P32 - P33 }\end{array}$ & Importance of observations \\
\hline $\begin{array}{l}\text { Questions } \\
\text { P24 - P26 }\end{array}$ & Completeness of the process \\
\hline $\begin{array}{l}\text { Questions } \\
\text { P15, P17, P21 }\end{array}$ & Process assistance type \\
\hline $\begin{array}{l}\text { Questions } \\
\text { P13-P14 }\end{array}$ & Need for triangulation and universalism \\
\hline
\end{tabular}

Figure 3. Factors determining the quality of research processes in management sciences. Source: the author's own work.

Application and purposefulness in practice - the factor understood as an opportunity to fulfil a scientific target, i.e. opportunity to implement the research process in question into the operation of companies and real economic life.

Impact of diversity of problems onto the process - the factor understood as an answer to the question how the selected research problem will determine further research actions?

Influence of a researcher - the factor that associates with the scope of free decisions taken by the researcher while dealing with a problem.

Unique character of a scientific discipline - the factor shows differences in how practitioners and theoreticians evaluate the selected methods, which makes it difficult to assess, in an objective way, the verifiability of the conducted research studies.

Importance of observations - the factor shows the impact of two types of observation. The first type of observation deals with the opportunity to co-operate with other entities, the second types involves, the so-called observation followed by a possible intervention

Completeness of the process - the factor is understood as an opportunity to divide the research process into stages that form a complementary whole, i.e.:

- $\quad$ Combining qualitative and quantitative methods.

- Elaborating a unique tool, model, approach to the way a method or procedure is selected.

- Indicating recommendations as to scientific and practical aspects.

A type of a supported process - the factor is understood as an impact on the course and management of the research process by means of pilot studies and case studies.

The need for triangulation and universalism of the conducted research - the factor shows, to a certain extent, a forced requirement for the management sciences to develop. However, a failure in meeting the requirements does not necessarily mean a failure in finding an original solution to the research problem.

\section{Influence of the practical approach (universalism, purposefulness) on the quality of \\ a research process}

In the surveyed sample $86.54 \%$ (i.e. $53.62 \%$ - strongly agree; $32.92 \%$ - agree) of respondents claim that the purpose of the management science discipline is to support the economic life from the practical point of view. Moreover, $88.53 \%$ of the surveyed underlined that it is necessary for research works, within the scope of the management sciences, to be set both in theory and in practice. It needs to be highlighted that as few as $23.20 \%$ of respondents underlined the lack of universal character of the elaborated concepts, problem solutions in the management sciences. It might be explained by the belief on the employment of popular research methods, techniques and procedures, instead of looking for pioneering solutions. It is also reflected in research findings in which $80.05 \%$ of representatives of the science claim that the verification of methods, models or procedures is a prerequisite, allowing to combine management science and practice. Moreover, there was also an increased interest of the academic circle $(88.77 \%)$ in the necessity to elaborate a model, procedure, and tool or approach supporting the matching of relevant methods or techniques to the research process.

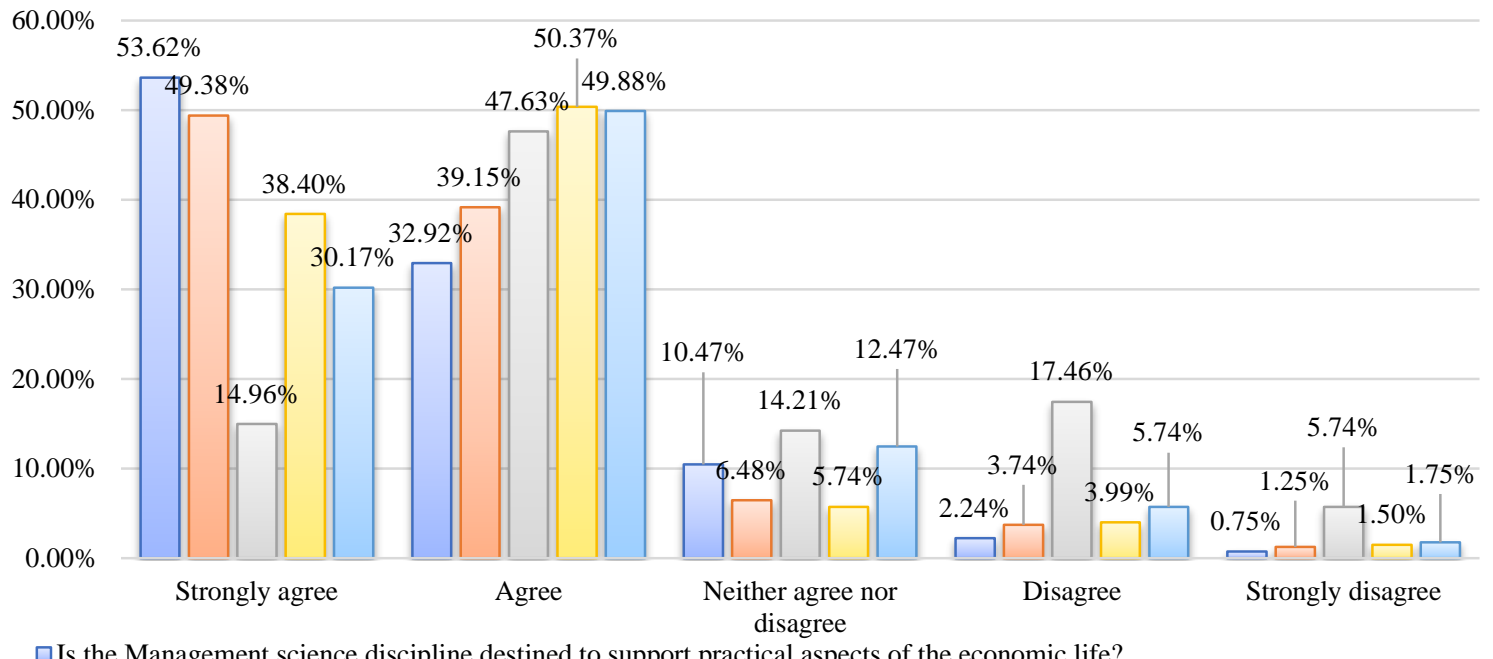

$\square$ Is the Management science discipline destined to support practical aspects of the economic life?

$\square$ Is it necessary that the research studies, carried out within the scope of the Management science discipline, be practically and theoretically set?

$\square$ Is there universalism of elaborated concepts, solutions to problems in the management sciences?

$\square$ Is it necessary to create a model, procedure, tool or approach for the sake of a research process?

$\square$ Is the verification of elaborated methods models or procedures a prerequisite to combine management science and practice? 
Figure 4. Influence of the practical approach on the quality of a research process - research findings. Source: the author's own work.

When analysing the presented research results, one should, at first, underline the considerable influence of the practical approach on the quality of a research process. To a considerable extent the influence should be based on translating the research process into the reality of companies and economic life, not only with reference to its verification, but also to the application.

\section{Necessity to Differentiate Research Methods in Research Processes}

In the sample in question, $82.29 \%$ of respondents claim that methodological triangulation support the research process. What is more, $69.08 \%$ of surveyed researchers emphasise that the triangulation is a precondition in the management sciences.
The achieved findings were also confirmed by an extensive literature study referring to the research methodology. It was stated in the said literature that the employment of numerous differentiated methods in the research process allows to adopt a complex approach to a research problem, while providing it with a broader image.

Methodological triangulation is an answer to the problem of selecting just one adequate method, since the problem might undoubtedly distort the research findings. In the beginning, a researcher should assume that selecting a few good methods will result in more comprehensive information and will allow to find out more about the phenomenon, instead of focusing on selecting the best method. It was confirmed by the findings, in which:

- $\quad 75.31 \%$ of respondents highlight the significant influence of qualitative factors, difficult to measure, on the quality of a research process,

- $\quad 88.28 \%$ of the surveyed unanimously highlight the influence of pilot surveys on the course of a research process.

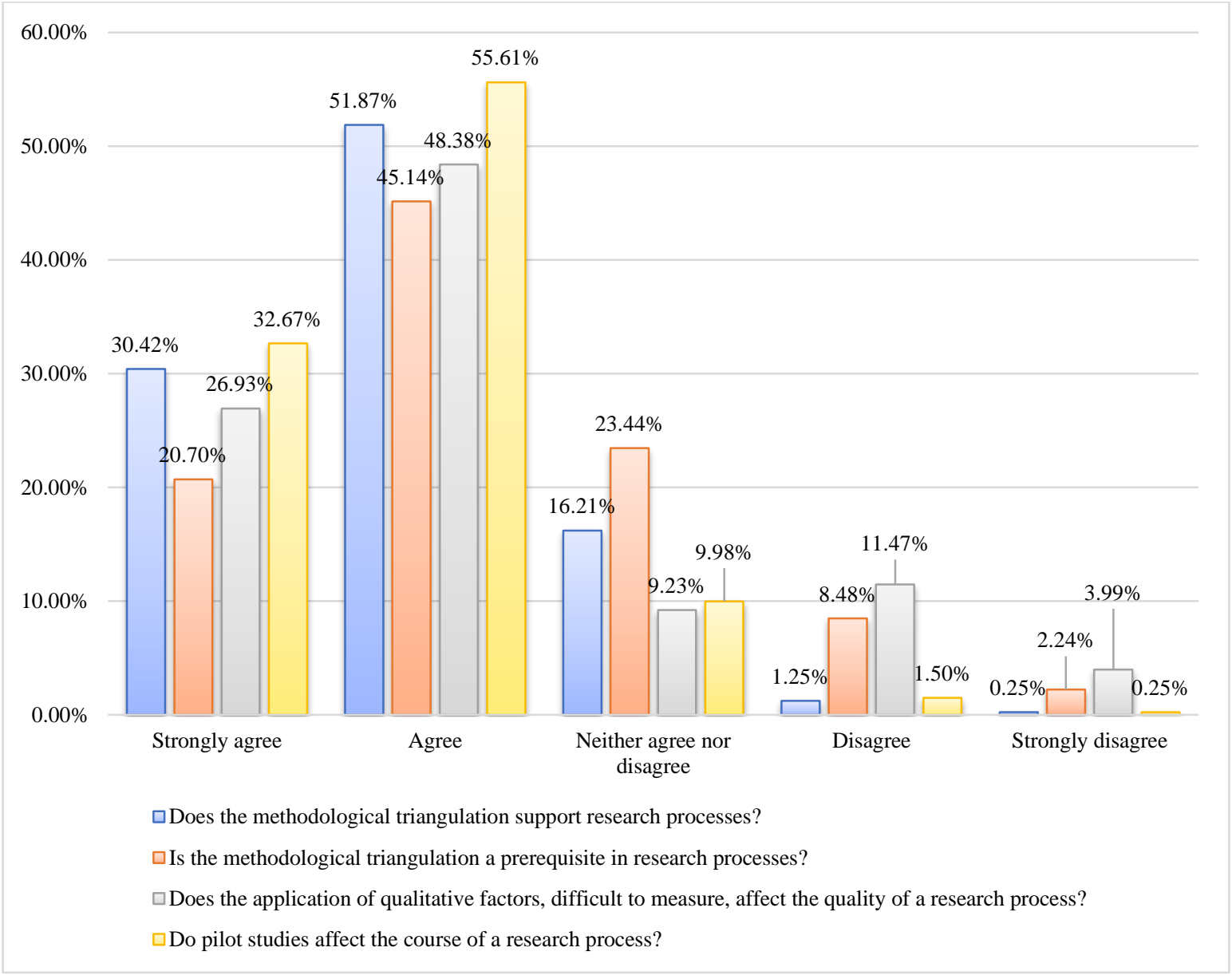

Figure 5. Differentiation of research methods in research processes - research findings. Source: the author's own work.

\section{Conclusion}

The aim of the article was to determine factors that would influence the quality of a research process, as an element that supplements currently used methodology-related approaches. As a result of research efforts, including conducted empirical studies, the main aim hereof and detailed aims were achieved. Upon the achievement of the aims and finding answers to research question, one was able to verify positively the adopted hypothesis.

Findings derived from the analysis of foreign and national literature on the methodology of conducting a research process include thoughts on transformations occurring over the years. The transformations covered the management methods which allowed to analyse conditions of organisations. The management methodology is constantly expanding by new methods, the latter being of diverse cognitive and practical effectiveness. A constant growth of diagnostic instruments has been dependent, mainly, on changes occurring in the environment; moreover, it is connected to the need to make use of more sophisticated and effective tools.

On the basis of analyses of main constituents, eight factors were identified. The factors, determining the quality of research processes, are as follows:

1. Practical application and purposefulness.

2. Influence of diverse research problems on the process.

3. Influence of a researcher on the research process.

4. Unique character of a scientific discipline.

5. Importance of observations.

6. Completeness of the process.

7. Process assistance type.

8. Need for triangulation and universalism 
It needs to be borne in mind that, depending on a subject covered in doctoral or post-doctoral theses, some of the above-mentioned factors do not necessarily have to be reflected in science or practice, nor should their importance be ignored. The abovementioned factors allow to evaluate the quality of the research process in question. The notion of the quality of the research process in management sciences should be understood as an opportunity to verify a level of execution and coherence of aims of theses with research problems and conclusions contained therein.

The influence of the practical approach on the quality of a research process explicitly indicates that it is difficult, as early as at the stage of defining a research problem, to select just one method that would allow to diagnose a problem fully and comprehensively. It is thus necessary to employ various research methods that would give a complex answer to the posed problem. The very development of heterogenous cognitive methods, modelling or organisation management has an impact on the necessity to adopt an open-minded approach, allowing or even encouraging to combine numerous approaches and methods.

Owing to the carried-out research on the necessity to differentiate research methods in research processes, one was able to determine the application ratio of particular methods and techniques, i.e. their combination. What is more, it was possible to identify some principles as to perceiving the research process in this context, as well as other variables that might influence the importance of an adequate selection of methods and techniques for the sake of research process in the management sciences, in order to improve the credibility, level and quality of research being carried out. Furthermore, it was stated that the use of differentiated methods in the research process allows to tackle the research problem seriously, providing, at the same time, a broader picture.

With reference to the foregoing, it is recommended to carry out detailed research as to the use of methods and techniques in the research process, and to make a research effort to elaborate a tool, method or procedure that would allow to match, in an adequate way, research methods and techniques with the research process within the scope of management sciences, with a consideration given to factors that determine the quality of the research process.

\section{Bibliography}

i. Ares, G., Varela, P. (Eds.) (2018). Methods in Consumer Research, Volume 1: New Approaches to Classic Methods. Elsevier, Duxford, UK: Woodhead Publishing.

ii. Ares, G., Varela, P. (Eds.) (2018). Methods in Consumer Research, Volume 2: Alternative Approaches and Special Applications. Elsevier, Duxford, UK: Woodhead Publishing.

iii. $\quad$ Boland, A., Cherry, G., Dickson, R. (Eds.) (2017). Doing a Systematic Review: A Student's Guide. London: Sage.

iv. Coghlan, D., Shani, A.B. (Eds.) (2016), Action Research in Business and Management (Fundamentals of Applied Research). London: Sage.

v. Collins, H. (2010). Creative research. The theory and practice of research for the creative industries. Lausanne, Switzerland: AVA Publishing SA.

vi. Czopek, A. (2013). Analiza porównawcza efektywności metod redukcji zmiennych - analiza składowych głównych i analiza czynnikowa. Studia Ekonomiczne, 132. Katowice: Uniwersytet Ekonomiczny.

vii. Denzin, N. (1970). The Research Act: Theorethical Introduction to Sociological Methods. Chicago: Aldine.

viii. Fojud, A., Boniecki, P., Zaborowicz, M., Lisak, D., Ślósarz, P., Stanisz, M., Strzeliński, P., Konieczny, A. (2017). Project of a computer system supporting extraction of the characteristics of pork half-carcases. Journal of Research and Application in Agricultural Engineering, 62(3).

ix. Gerring, J. (2017). Case Study Research: Principles and Practices (Strategies for Social Inquiry). New York: Cambridge University Press.

x. Harrington, H.J., Voehl, F. (Eds.) (2016). The Innovation Tools Handbook, Volume 1: Organizational and Operational Tools, Methods, and Techniques that
Every Innovator Must Know. Boca Raton, FL, USA: CRC Press.

xi. Hempoliński, M. (1992). Krytyka epistemologii fundamentalistycznej: R. Rorty i W.V.O. Quine. In J. Niżnik (ed.), Pogranicza epistemologii. Warszawa: 1FiS PAN.

xii. Jokiel, G. (2006). O celach nauki organizacji i zarządzania. Prace Naukowe, 1104. Wrocław: Akademia Ekonomiczna.

xiii. Koźmiński, A.K. (2011). Reaktywacja. Warszawa: Poltext.

xiv. Kukuła, K. (2007). Elementy statystyki $w$ zadaniach. Warszawa: PWN.

xv. Labarca, C. (2017). Qualitative Research for beginners. Maracaibo, Venezuela.

xvi. Malska, W. (2017). Wybrane aspekty wnioskowania statystycznego. Edukacja-Technika-Informatyka, 8(3).

xvii. Mooi, E., Sarstedt, M., Mooi-Reci, I. (2018). Market research. The process, data, and methods using stata. Singapore: Springer Nature.

xviii. Niemczyk, J. (2011). Metodologia nauk o zarzadzaniu. In W. Czakon (ed.), Podstawy metodologii badan in the management sciences. Warszawa: Wolters Kluwer business.

xix. O'Leary, Z. (2017). The Essential Guide to Doing Your Research Project. London: Sage.

xx. O'Leary, Z., Hunt, J.S. (2016). Workplace Research: Conducting small-scale research in organizations. London: Sage.

xxi. Petrova, V.M. (Ed.) (2018). Advances in Engineering Research. New York: Nova Science Pub Inc.

xxii. Punch, K.F. (2016). Developing Effective Research Proposals. London: Sage.

xxiii. Quian, D. (2018). Adaptive Control: Methods, Applications and Research. Nova Science Publishers, Inc.

xxiv. Quinton, S., Reynolds, N. (2018). Understanding Research in the Digital Age. London: Sage.

xxv. Robbins, D. (2009). Understanding research methods. A guide for the public and nonprofit manager. Boca Raton, USA: CRC Press, Taylor \& Francis Group.

xxvi. Singleton, R.A., Straits, B.C. (2017). Approaches to Social Research. England: Oxford University Press.

xxvii. Sloan, L., Quan-Haase, A. (Eds.) (2017). The SAGE Handbook of Social Media Research Methods. London: Sage.

xxviii. Sudoł, S. (2007). Nauki o zarządzaniu. Węzłowe problemy $i$ kontrowersje. Toruń: Dom Organizatora.

xxix. Sudoł, S. (2012). Nauki o zarzadzaniu. Warszawa: PWE.

xxx. Sułkowski, Ł. (2010). Etos nauk o zarządzaniu. In H. Jagoda, L. Lichtarski (eds.), Kierunki i dylematy rozwoju nauk i praktyki zarządzania przedsiębiorstwem. Wrocław: Uniwersytet Ekonomiczny.

xxxi. Thomas, G. (2017). How to Do Your Research Project: A Guide for Students. London: Sage.

xxxii. Trajer, J., Paszek, A., Iwan, S. (2012). Zarzązanie wiedza. Warszawa: PWE.

xxxiii. Weber, M. (2011). Methodology of Social Sciences. New York: Routledge. 